\title{
Physical and Sensory Quality of Broiler Meat as Influenced by Dietary Supplementation of Turmeric (Curcuma longa), Garlic (Allium sativum) and in Combinations as a Feed Additive
}

\author{
Sri Purwanti ${ }^{1, *}$, Zuprizal ${ }^{2}$, Tri Yuwanta ${ }^{2}$ and Supadmo ${ }^{2}$ \\ ${ }^{1}$ Department of Animal Nutrition and Feed Science, Faculty of Animal Science, University of Hasanuddin,Jl. Perintis \\ Kemerdekaan KM. 10, Tamalanrea, Makassar, South Sulawesi, Indonesia \\ 2Department of Animal Nutrition, Faculty of Animal Science, University of Gadjah Mada, Jl. Fauna No. 03, Caturtunggal, \\ Yogyakarta 5528, Indonesia \\ *Corresponding author e-mail: sripurwanti@unhas.ac.id
}

\begin{abstract}
This research was conducted to evaluate the effect of turmeric water extract, garlic and combinations of turmeric and garlic as feed additives in broiler diets on the physical and sensory quality of broiler meat. During the study, the chicken were given 5 feeding treatments, i.e. RO (basal ration without phytobiotic and antibiotics) , R1 (basal diet $+0.015 \%$ zinc bacitracin $+2.485 \%$ filler), R2 (basal ration $+2.50 \% \mathrm{TE}$ ), R4 (basal ration $+2.00 \%$ $\mathrm{GE}+0.50 \%$ filler), and R5 (basal ration $+2.50 \% \mathrm{TGE}$ ). The base diet was composed of: yellow corn, meat and bone meal, poultry meat meal, soybean meal, oil, mineral mix, calcium carbonate, dicalcium phosphate, salt, Llysine- $\mathrm{HCl}$, and $\mathrm{DL}-$ methionine. Variables observed were physical quality $\mathrm{(pH}$, water holding capacity, cooking lose, and tenderness) and sensory quality. Data regarding physical quality were statistically analyzed by one-way ANOVA followed by the orthogonal contrast for significant results, and data of sensory quality by non-parametric methods such as the Hedonic Kruskal-Wallis test. The results showed that the physical quality of meat had no effect $(P>0.05)$, except the significant water holding capacity $(P<0.05)$ which was lower with phytobiotic extract supplementation. All sensory test parameters in fresh and cooked meat had no effect $(P>0.05)$ following phytobiotic extract supplementation, except for the color and acceptability $(P<0.05)$ in fresh broiler meat. The conclusion of the research was that $2.5 \% \mathrm{TE}, 2.0 \% \mathrm{GE}$ and $2.5 \% \mathrm{TGE}$ is capable of acting as a feed additive to increase the physical and sensory quality of broiler meat.
\end{abstract}

Key words: meat, phytobiotic, feed additive, physical quality, sensory quality

Abstrak. Penelitian ini dilakukan untuk mengevaluasi pengaruh ekstrak air kunyit, bawang putih dan kombinasi kunyit dan bawang putih sebagai feed additive pada ransum terhadap kualitas fisik dan sensoris daging broiler. Selama penelitian, ayam diberi 5 perlakuan pakan, yaitu R0 (ransum basal tanpa antibiotik dan fitobiotik), R1 (ransum basal + zinc basitracin 0,015\% + filler 2,485\%), R2 (ransum basal + ekstrak kunyit 2,50\%), R4 (ransum basal + ekstrak bawang putih 2,00\% + filler 0.50\%), dan R5 (ransum basal + ekstrak kunyit dan bawang putih 2,50\%). Ransum basal terdiri dari: jagung kuning, MBM, PMM, bungkil kedelai, minyak nabati, premiks, $\mathrm{CaCO}_{3}$, $\mathrm{DCP}, \mathrm{NaCl}, \mathrm{L}-\mathrm{lisin}-\mathrm{HCl}$, dan DL-metionin. Variabel yang diamati adalah kualitas fisik (pH, daya ikat air,susut masak, dan keempukan) dan kualitas sensorik. Data mengenai kualitas fisik dianalisis secara statistik dengan ANOVA satu arah diikuti oleh kontras ortogonal untuk hasil yang signifikan, dan data kualitas sensorik dengan metode non-parametrik seperti uji Hedonic Kruskal-Wallis. Hasil penelitian menunjukkan bahwa kualitas fisik daging tidak berpengaruh $(P>0,05)$, kecuali daya ikat air secara signifikan $(P<0,05)$ yang lebih rendah dengan suplementasi ekstrak fitobiotik. Semua parameter uji sensorik pada daging segar dan dimasak tidak berpengaruh $(P>0,05)$ dengan penambahan ekstrak fitobiotik, kecuali untuk warna dan daya terima $(P<0,05)$ pada daging ayam pedaging segar. Kesimpulan dari penelitian ini adalah bahwa ekstrak kunyit 2,5\%, ekstrak bawang putih 2,0\% dan kombinasi ekstrak kunyit dan bawang putih 2,5\% mampu bertindak sebagai feed additive untuk meningkatkan kualitas fisik dan sensoris daging broiler.

Kata kunci: daging, fitobiotik, feed additive, kualitas fisik, kualitas sensoris

\section{Introduction}

The increasing awareness of the importance of animal protein with the improvement of socioeconomic demand for food from cattle is increasing, thus causing an increase in demand for livestock production. In line with the increasing intelligence of the people, they are also more selective in choosing livestock products, including meat broiler. The acceptability of meat products is judged not only using the mouth and nose but also by using the 
eye (which can be viewed on the appearance of the product) in the assessment. Sensorial attributes include flavor and texture palatability associated with meat products. All of these aspects have an important impact on consumers in selecting products. Of course, this is a result of the ability to find alternatives to poultry for quality feed additives, which are sufficient, readily available, and proven to be beneficial for the animals. Phytobiotics are known to have pharmacological effects and are widely used in traditional medicine. Leaves, roots, flowers and whole plants are used for the production of phytobiotic products. Products may comprise the dried form of whole plants or their parts or extracts of some valuable ingredients (Grashorn, 2010). The utilization of phytobiotics as Natural Growth Promoters (NGPs) has been identified as an effective alternative to antibiotics.

Phytobiotics such as NGPs are highly developed as feed additives, and for immunity, improving performance and being highly effective in improving the health of the digestive tract (Panda et al., 2009; Purwanti et al., 2014a); they also stimulate livestock nutrition and have antimicrobial, and antihelmintic-coccidiostatic properties (Panda et al., 2006). Combination phytobiotics are found in curcumin and garlic extract (1TE:3GE) and can act as anti-bacterial and be used as alternatives to feed additives (Purwanti et al., 2014b).

Sarica et al. (2005) reported that garlic meal supplementation reduced the population of pathogenic coliform in the gut of broiler chickens. In addition, Gorinstein et al. (2005) and Kim et al. (2009) reported that garlic products have anti-oxidative properties in broiler chickens and layer hens. Other beneficial effects of garlic include lowering cholesterol and triglyceride levels, and preventing atherosclerosis due to the anti-thrombotic, antiplatelet, anti- hypertensive, and anti-lipidemic properties (Ali et al., 2000; Tattelman, 2005; Amagase, 2006; CorzoMartǐnez et al., 2007). Commercial curcumin contains three main components, namely curcumin $(77 \%)$, demethoxycurcumin $(17 \%)$ and bisdemethoxycurcumin (3\%), all of which are referred to as curcuminoids (Aggarwal et al., 2003). Curcumin is the main active compound that furnishes turmeric with its characteristic yellow color and is recognized as being responsible for most of its therapeutic effects, including antibacterial, antifungal, antiprotozoal, antiviral, antioxidant, anti-inflammatory, and hypocholesterolemic activities (Chattopadhyay et al., 2004). Feeding diets containing phytobiotics may result in the inhibition of growth, and the colonization of enteropathogenic microbes in the digestive tract, thus contributing to the balance of gut microflora (Harris et al., 2001), and promoting the growth performance and health of birds (Adibmoradi et al., 2006).

Factors that determine the delicacy and acceptability of meat include color, waterholding capacity (WHC), the impression of meat juices (juiciness), texture, tenderness, taste or flavor, and the $\mathrm{pH}$ of the meat (Soeparno, 2005). The physical quality and sensory food (Isleten and Karagul-Yuceer, 2006) including meat will determine the acceptability of consumers against meat to be consumed which can be influenced in part by feed (Sami et al., 2004; Soeparno, 2005; Mullen et al., 2006). The purpose of this study to determine the physical and sensory quality of broiler meat is to get supplementary water extracts from turmeric and garlic.

\section{Materials and Methods}

Experimental birds. One hundred commercial broiler chicks of the Cobb strain, were used in this study. They were kept in cages and randomly allotted into five treatments with four replicates of five chicks each.

Experimental diet: The experimental diet was formulated according to the standards prescribed in National Research Council (1994). RO was offered a basal diet, and served as a negative control, group 2 was offered a basal diet with $0.015 \%$ Zinc bacitracin as a positive control, 
and groups 3, 4 and 5 were offered a basal diet with $0.25 \%$ turmeric extract (TE), $0.20 \%$ garlic extract (GE) and $0.25 \%$ turmeric and garlic extract (TGE), respectively, during a six-week experimental period. Feed and water were provided ad libitum to the birds throughout the experimental period. The ingredients and nutrient composition of the experimental diet are shown in Table 1. Rations were formulated every week and turmeric and garlic extracts were added before being properly hand-mixed to ensure the homogeneous distribution of the extract.

The physical quality of broiler meat. Samples were taken and the $\mathrm{pH}$ of the meat was tested with the modified method of Button et al. (1972). Water holding capacity was determined by the method of Hamm (Soeparno, 2005), cooking loss (Soeparno, 2005), and tenderness of the meat with the shear press method, as a modified Warner-Bratzler method (Soeparno, 2005).

Sensory quality of broiler meat. Sensory qualities include color, flavor, texture, juiciness, tenderness, and acceptance. Meat sensory tests were conducted with a sample of meat that had been cooked without salt or spices. Testing was undertaken using the meat sensory panelists, including as many as 15 individuals who are not trained with the scoring method.

Statistical analysis. Data for all parameters were subjected to an analysis of variance. The treatments mean with significant differences at $\mathrm{P}<0.05$ were compared using the orthogonal contrast procedure (Gomez and Gomez, 1984). Sensory qualities (color, taste, texture, juiciness, tenderness, and acceptance) were tabulated and tested with non-parametric analysis through the Hedonic Kruskal-Wallis test (Steel and Torrie, 1995).

\section{Results and Discussion}

\section{Physical Quality of Broiler Meat}

pH. The $\mathrm{pH}$ of different treatments is presented in Table 1. Statistical analysis showed that the addition of $2.5 \% \mathrm{TE}, 2.0 \% \mathrm{GE}$, and $2.5 \% \mathrm{TGE}$ in feed did not affect the $\mathrm{pH}$ value of broiler meat $(P>0.05)$. This is presumably because the active compounds contained in extracts of turmeric and garlic extract cannot affect muscle glycogen levels, so the process of glycolysis is not very different. Likewise, the content of lactic acid, which causes a decrease in $\mathrm{pH}$, is also no different. Increased lactic acid can lower the $\mathrm{pH}$; the higher the content of lactic acid in muscle, the lower the $\mathrm{pH}$ value obtained. Lactic acid is relatively the same after cutting and there are ultimately no differences in the $\mathrm{pH}$ values. Therefore, after death, the $\mathrm{pH}$ between the control and treatment is not different. The normal $\mathrm{pH}$ value of broiler meat ranged from 5.96-6.07 (Van Laack et al., 2000), while the pH value of broiler meat research results ranged from 5.53-5.70. The $\mathrm{pH}$ of these results is below the value obtained by Abdullah et al. (2010) using $1.0 \%$ garlic powder; the $\mathrm{pH}$ value reported was 6.04 , and at the level of $0.25 \%$ was 5.94 .

Table1. The mean value of $\mathrm{pH}$, water holding capacity, cooking losses, and tenderness of broiler's meat supplemented $2.5 \% \mathrm{TE}, 2.0 \% \mathrm{GE}$ and $2.5 \% \mathrm{TGE}$ on feed

\begin{tabular}{|c|c|c|c|c|c|}
\hline \multirow[t]{3}{*}{ Parameters } & \multicolumn{5}{|c|}{ Treatments } \\
\hline & Negative & Positive & $2.5 \%$ & $2.0 \%$ & $2.5 \%$ EAKBP \\
\hline & control & control & EAK & EABP & \\
\hline $\mathrm{pH}$ value $^{\mathrm{ns}}$ & $5.58 \pm 0.22$ & $5.53 \pm 0.26$ & $5.63 \pm 0.21$ & $5.65 \pm 0.13$ & $5.70 \pm 0.08$ \\
\hline Water holding capacity (\%) & $22.65^{\mathrm{a}} \pm 5.13$ & $19.03^{\mathrm{a}} \pm 3.07$ & $18.88^{\mathrm{b}} \pm 1.99$ & $12.44^{\mathrm{c}} \pm 1.56$ & $17.23^{b c} \pm 1.19$ \\
\hline Cooking lose $(\%)^{\text {ns }}$ & $21.68 \pm 3.49$ & $23.46 \pm 2.68$ & $23.34 \pm 1.18$ & $24.79 \pm 4.43$ & $22.19 \pm 1.93$ \\
\hline Tenderness $(\mathrm{kg} / \mathrm{cm} 2)^{\mathrm{ns}}$ & $1.45 \pm 0.36$ & $1.19 \pm 0.17$ & $2.12 \pm 1.19$ & $1.30 \pm 0.32$ & $1.14 \pm 0.18$ \\
\hline
\end{tabular}

Note: ${ }^{\text {ns }}$ non significant; ${ }^{\text {abc }}$ Different superscript at the same raw indicate significantly different $(\mathrm{P}<0.05)$. 
A decrease in $\mathrm{pH}$ and the final value to be reached is the ultimate $\mathrm{pH}$ is very important in the physical quality of the meat. According to Lawrie (1995), the meat is alkaline (6.0-6.5) meaning that bacteria will quickly evolve from the meat in a state of acid with $\mathrm{pH}$ 5.3-5.7. According to Soeparno (2009), factors that affect the rate and magnitude of the decline in postmortem $\mathrm{pH}$ can be divided into two groups: intrinsic factors and extrinsic factors. Intrinsic factors include muscle glycogen and variability among cattle, whereas extrinsic factors include ambient temperature, treatment additives before cutting and stress before slaughter.

Water holding capacity (WHC). The results of statistical analysis showed that the phytobiotic effect of extract supplementation $(P<0.05)$ affected the water holding capacity of broiler meat. In contrast, tests of contrast II showed that supplementation with $2.5 \%$ TE lowered the levels of $\mathrm{WHC}(\mathrm{P}<0.05)$ compared to $2.0 \% \mathrm{GE}$ from $18.88 \%$ to $12.44 \%$; also, in contrast IV, it was shown that supplementation of the negative control decreased $(\mathrm{P}<0.05) \quad \mathrm{WHC}$ against supplementation with $2.5 \% \mathrm{TE}$ (18.88\%), $2.0 \% \mathrm{GE}$ (12.44\%), and 2.5\% TGE (17.24\%).

Soeparno (1992) reported that the WHC of broiler meat at the age of 6 and 7 weeks was about $22.19 \%$ and $28.54 \%$, whereas the WHC of broiler meat research results ranged from $12.44-$ $22.65 \%$. Soeparno (2011) stated that meat with a higher intramuscular fat content can also have high WHC, possibly because intramuscular fat "loosens" the microstructure of the meat and provides a larger space for protein-protein meat to bind water molecules. The highest WHC of $22.65 \%$ is in the negative control treatment, due to the high protein content of meat in the treatment of $23.90 \%$; the lowest water holding capacity is $12.44 \%$, which was obtained for the treatment supplemented with $2.0 \% \mathrm{GE}$; this is due to the amount of water associated with a muscle protein that is free to leave the muscle fibers so that the protein content of the meat is low at $20.37 \%$. Hamm (1981) suggests that changes in the WHC of meat are allegedly due to changes in the ions in the protein meat. The decline in WHC due to the increasing amount of lactic acid that accumulates, as a result, many myofibrillar proteins being damaged; this is followed by the loss of a protein's ability to bind water. The high protein content of meat is followed by a higher water-binding power. Water holding capacity is strongly influenced by the $\mathrm{pH}$ of the meat; the meat $\mathrm{pH}$ study results ranged from 5.53-5.70. Pearson and Young (1989) argue that as the $\mathrm{pH}$ of the meat increases, the water holding capacity also increases. The low $\mathrm{pH}$ value of meat results in an open flesh structure, so that the lower water holding capacity and high $\mathrm{pH}$ of the meat results in an enclosed structure and high water holding capacity of the meat (Buckle et al., 1985; Boutonet al., 1971). Soeparno (2005) states that high and low grades are the embodiment of the isoelectric point of the protein-protein bonds in meat. At lower $\mathrm{pH}$ than the isoelectric point of the protein-protein meat, there is an excess positive charge which results in the rejection of myofilament and provides more space for water molecules, so the WHC increases.

Cooking Loss. The results of statistical analyses showed that supplementation with $2.5 \% \mathrm{TE}$, $2.0 \% \mathrm{GE}$, and $2.5 \% \mathrm{TGE}$ in feed does not affect ( $P>0.05$ ) cooking loss of broiler meat. Soeparno (2005) reported that cooking shrinkage varies between $15 \%$ and $40 \%$ in general, whereas broiler meat cooking shrinkage results in the study ranged from $21.68-24.79 \%$. It is thought that the cooking loss value increases because of the declining value of the holding capacity of meat. Soeparno (2005) states that the shrinkage has a negative relationship with the cooking water holding capacity. The low WHC will result in high value cooking shrinkage (Aulia et al., 2005). The cooking loss is highest (24.79\%) with supplementation of $2.0 \% \mathrm{TGE}$, with a result of $24.79 \%$. This is due to the low value of the water holding capacity of the treatment being $12.44 \%$, thereby increasing the percentage of cooking 
loss. High cooking loss values are associated with intramuscular fat content in the meat. Most of the cholesterol forms a layer of fat from the plasma membrane. The cholesterol content is low on average with the treatment given the extract phytobiotics. Low cholesterol may result in low WHC and high value cooking losses compared to the control treatment, which showed high cholesterol content and lowers cooking shrinkage values, especially in the negative control. Abdullah et al. (2010) reported that supplementation with $0.25 \%, 0.50 \%$, and $1.00 \%$ garlic powder gave a cooking loss of $24.60 \%, 24.30 \%$, and $24.30 \%$, respectively, which was still higher the control of $23.70 \%$.

Tenderness. The results of the statistical analysis showed that the phytobiotic extraction feed supplementation did not affect $(P>0.05)$ the tenderness of broiler meat. Lyon et al. (2004) reported that the tenderness of broiler chickens ranged between 1.82 and $2.19 \mathrm{~kg} / \mathrm{cm}^{2}$, while the rate of broiler meat tenderness research ranged from $1.14-2.12 \mathrm{~kg} / \mathrm{cm}^{2}$. Differences in the level of the tenderness of meat were due to the influence of $\mathrm{pH}$ value, $\mathrm{WHC}$ and cooking loss of broiler meat. Lawrie (1979) states that tenderness can be attributed to three categories of muscle protein: a protein of connective tissue (collagen, elastin, reticulin and mucopolysaccharide matrix), myofibrils (especially myosin, actin, and tropomyosin) and sarcoplasmic (sarcoplasmic proteins and the sarcoplasmic reticulum).

Collagen is the principal structural protein in connective tissue and has a great influence on the toughness of the meat. Collagen levels are influenced by the fat content of meat. A relatively high fat content will dissolve or degrade collagen. Supplementation with $2.5 \%$ TGE gives low grade tenderness among treatments with phytobiotic extract supplementations. The fat content in $2.5 \%$ TGE is quite low, with a meat cholesterol content of $46.98 \mathrm{mg} / 100 \mathrm{~g}$ and a tenderness of $1.14 \mathrm{~kg} / \mathrm{cm}^{2}$, while supplementation with $2.5 \%$ TE cholesterol is $1.61 \mathrm{mg} / 100 \mathrm{~g}$ and tenderness is $2.12 \mathrm{~kg} / \mathrm{cm}^{2}$. Low fat content will make the collagen content increase and the meat will be tender.

\section{Sensory Qualities}

Color. The test results are statistically meat color Hedonic Kruskal Wallis analysis results indicate that the raw broiler meat with phytobiotic extract supplementation in the diet affect $(P<0.05)$ to the color of the meat with color score ranged from 2.13 - 5.00, which means yellow to white. Muscle tone can be associated with the type of muscle fibers or ATPase activity. Aerobic muscle fibers which generally have a dark color activate ATPase and cause weak and slow contractions. Curcumin found in turmeric is known to give a yellow pigment. Curcumin can induce some kinds of molecules such as proteins, enzymes or receptors. One of the enzymes that are induced is ATPase (Anand et al., 2008).

Ravindranath (1980) reported that administration of curcumin orally $400 \mathrm{mg}$ in mice will result in the accumulation of curcumin in small amounts and does not change in the liver and kidneys. Thirty minutes after the administration of curcumin, $90 \%$ will be found in the stomach and small intestine, while only $1 \%$ will be found in these organs after 24 hours. A related study conducted by Pan et al. (1999), using mice given a dose of $1 \mathrm{~g} / \mathrm{kg}$ curcumin via intraperitoneal injection, showed the distribution of curcumin in a number of organs; the highest level was in the intestine $(117 \mu \mathrm{g} / \mathrm{g})$ 1 hour after the administration of curcumin. Moderate amounts are found in the spleen, liver, and kidneys and little curcumin is found in brain tissue. This suggests that curcumin is distributed throughout the body, but when it reaches the tissue, levels of curcumin are reduced compared to the time of administration. Curcumin is a lipophilic molecule that is widely metabolized in the gastrointestinal tract and liver after oral administration. 
Table2.The score of color, taste, texture, juiciness, tenderness, and acceptability of fresh and cook broiler's meat supplemented 2.5\% TE, 2.0\% GE and 2.5\% TGE on feed

\begin{tabular}{|c|c|c|c|c|c|}
\hline \multirow[t]{2}{*}{ Variables } & \multicolumn{5}{|c|}{ Treatments } \\
\hline & $\begin{array}{l}\text { Negative } \\
\text { control }\end{array}$ & $\begin{array}{l}\text { Positive } \\
\text { control }\end{array}$ & $2.5 \% \mathrm{TE}$ & $2.0 \% \mathrm{GE}$ & $2.5 \% \mathrm{TGE}$ \\
\hline \multicolumn{6}{|l|}{ Fresh meat } \\
\hline Color* & $5.00^{\mathrm{e}} \pm 0.00$ & $3.73^{d} \pm 0.46$ & $2.13^{\mathrm{a}} \pm 0.99$ & $2.86^{b} \pm 0.74$ & $3.20^{c} \pm 0.77$ \\
\hline Texture $^{\text {ns }}$ & $3.80 \pm 0.68$ & $3.53 \pm 0.74$ & $3.53 \pm 0.74$ & $3.47 \pm 0.74$ & $3.47 \pm 0.92$ \\
\hline Juiceness $^{\text {ns }}$ & $3.60 \pm 0.51$ & $3.40 \pm 0.74$ & $3.13 \pm 0.99$ & $3.47 \pm 0.83$ & $3.27 \pm 0.88$ \\
\hline Acceptability & $2.60^{\mathrm{a}} \pm 1.06$ & $3.53^{c} \pm 0.52$ & $3.67^{\mathrm{bd}} \pm 1.18$ & $3.47^{b} \pm 0.99$ & $3.47^{b} \pm 0.74$ \\
\hline \multicolumn{6}{|l|}{ Cooking Meat } \\
\hline Colorns $^{\text {ns }}$ & $3.40 \pm 1.30$ & $3.67 \pm 1.11$ & $4.33 \pm 1.05$ & $3.93 \pm 1.10$ & $3.87 \pm 1.06$ \\
\hline Taste $^{\text {ns }}$ & $3.67 \pm 0.82$ & $3.53 \pm 0.83$ & $3.47 \pm 0.74$ & $3.27 \pm 1.16$ & $3.47 \pm 0.99$ \\
\hline Texture $^{\mathrm{ns}}$ & $3.53 \pm 0.64$ & $3.47 \pm 0.64$ & $3.33 \pm 0.62$ & $3.07 \pm 0.88$ & $3.20 \pm 0.94$ \\
\hline Juiceness $^{\text {ns }}$ & $3.20 \pm 0.68$ & $3.47 \pm 0.64$ & $3.07 \pm 0.80$ & $3.20 \pm 0.77$ & $3.40 \pm 0.91$ \\
\hline Tenderness ${ }^{\mathrm{ns}}$ & $3.73 \pm 0.70$ & $3.80 \pm 0.68$ & $3.40 \pm 0.83$ & $3.00 \pm 0.85$ & $3.67 \pm 1.05$ \\
\hline Acceptability $^{\text {ns }}$ & $3.60 \pm 1.06$ & $3.87 \pm 0.64$ & $3.33 \pm 0.98$ & $3.33 \pm 0.98$ & $3.67 \pm 1.05$ \\
\hline
\end{tabular}

Texture. The test results are statistically significant for meat texture using the hedonic Kruskal Wallis analysis; the results showed that the supplementation of fresh broiler meat and cooked meat with phytobiotic extract did not affect the texture of meat $(P>0.05)$. Fresh meat texture scores ranged from 3.47-3.80, which means the texture was smooth, while the cooked meat ranged from 3.07-3.53. These data indicate that supplementation with phytobiotic extract leaves the texture of broiler meat relatively the same and does not affect the muscle fibers when chicken meat is cut at the same age. Soeparno (2009) stated that the level of roughness of texture increases with age. A muscle with small muscle fibers did not show increased roughness with increasing age.

Taste. The test results are statistically significant for meat flavor using the hedonic Kruskal Wallis analysis; results indicate that the cooked broiler meat supplemented with phytobiotic extracts did not affect the flavor of the meat $(P>0.05)$. Scores for the flavor of the cooked meat ranged from 3.27-3.67, which means that the taste is more savory. Senses of broiler meat are relatively similar; rather tasteful. Soeparno (2009) states that smell and taste are determined by the precursor's water solubility and fat content, and the release of volatile substances (volatile) contained in the flesh. In a study to evaluate the product, it was reported that the supplementation of the diet of laying hens with $30 \mathrm{~g} / \mathrm{kg}$ garlic does not affect the taste of the eggs (Birrenkott et al., 2000). Sundari (2014) reported that nanocapsules of turmeric extract did not affect the taste of broiler meat. However, a study using the Arbor Acre male broilers showed that supplementation with 20 $\mathrm{g} / \mathrm{kg}$ of garlic in the diet increased the score for flavor (Kim et al., 2009).

Juiciness. The test results are statistically significant for juiciness using the hedonic Kruskal Wallis analysis; the results indicate that fresh broiler meat and cooked meat supplemented with phytobiotic extract did not affect the juiciness of the meat $(P>0.05)$. Scores for juiciness of raw meat ranged from 3.13-3.60, which means a little juice, while the juiciness of 
cooked meats ranged from 3.20-3.47. Feed has little effect on meat juice. Meat juice impression was influenced by fluid released during chewing and saliva produced by factors of flavor, including intramuscular fat. Additionally, juiciness is closely linked to the cooking loss of meat and age of the cattle. Low levels of meat juice can be caused by high levels of cooking loss and the levels of juice in the meat with a normal $\mathrm{pH}(5.4$ - 5.8) can be estimated from cooking loss (Soeparno, 2009). The results of this study indicate that supplementation with phytobiotic extracts did not affect cooking loss and the age of the chicken is also the same for all treatments that are thought to show relatively equal juiciness and meat $\mathrm{pH}$ levels in the normal range is 5.53-5.70. The meat is of good quality and contains more juice than low-quality meat.

Tenderness. Following statistical analysis using the hedonic Kruskal Wallis analysis, the results indicate that the supplementation of cooked broiler meat with phytobiotic extract in the diet did not affect the tenderness of the meat $(P>0.05)$. Cook meat tenderness scores ranged from 3.00-3.80, which means they are a bit soft and tender. Soeparno (2009) states that the tenderness of the meat is determined by the structure and status of myofibrillar contractions, the content of the connective tissue and the level of cross-bonding, water holding capacity by protein meat and meat juice. The overall impression of softness including meat texture can be determined subjectively and objectively. Test taste panel tenderness (subjective) impression is associated with meat juice and is an indication of the components of muscle fibers and connective tissue and cooking loss (sensitive to changes in the meat juice). The study provides relatively similar juiciness values among treatments in order to provide relatively the same softness.

Acceptability. Results of the tests for the acceptability of meat by hedonic Kruskal Wallis analysis showed that fresh broiler meat with phytobiotic extract supplementation in the diet affects the acceptability of meat $(P<0.05)$ with scores ranging from 2.60-3.67. Further tests showed that the negative control treatment was lower $(\mathrm{P}<0.05)$ than the positive control.

The panelists prefer treatment with the phytobiotic extracts of $2.5 \% \mathrm{TE}, 2.0 \% \mathrm{GE}$ and 2.5\% TGE compared to the control treatment; this relates to the supplementary treatment, with the color ranging from slightly yellow to yellow. This indicates that the panelists prefer fresh meat with a color that is slightly yellow to yellow rather than white; this means that the panelists were influenced by the phytobiotic extract supplementation with a preliminary assessment of the color of the meat. Results of statistical analysis of the cooked broiler meat following phytobiotic extract supplementation in the feed did not affect the acceptability of meat $(P>0.05)$. The average values given by panelists ranged from 3.33-3.87. Soeparno (1991) reported the value of meat based on the level of acceptability of consumers. Onibi et al. (2009) reported that supplementation with $0.5 \mathrm{~g} / \mathrm{kg}$ of garlic in broiler feed Shaver Starbo aged 7 weeks enhanced the odor of garlic but not the palatability of the meat.

\section{Conclusions}

In conclusion, there is evidence in this study to show that $2.5 \% \mathrm{TE}, 2.0 \% \mathrm{GE}$ and $2.5 \% \mathrm{TGE}$ were capable as a feed additive to increase the physical and sensory qualities of broiler meat.

\section{References}

Abdullah AY, KZ Mahmoud, BM Nusairat and RI Qudsieh. 2010. Small intestinal histology, production parameters, and meat quality as influenced by dietary supplementation of garlic (Allium sativum) in broiler chicks. Italian Journal of Animal Science. 9(80):414-418.

Adibmoradi M, B Navidshad, J Seifdavati and M Royan. 2006. Effect of dietary garlic meal on histological structure of small intestine in broiler chickens. Journal of Poultry Science.43:378-383.

Ali M, M Thomson and M Afzal. 2000. Garlic and onions: their effect on eicosanoid metabolism and 
its clinical relevance. Prostaglandins, Leukotrienes and Essential Fatty Acids. 62(2):55-73.

Aggarwal B B, K Anushree and AC Bharti. 2003 Anticancer potential of curcumin: Preclinical and Clinical Studies. Anticancer Research.23:363-398.

Amagase H. 2006. Clarifying the real bioactive constituents of garlic. Journal of Nutrition. 136:716S-725S.

Anand $P, C$ Sundaram, S Jhurani, AB Kunnumakkara and BB Aggarwal. 2008. Curcumin and cancer: an "old-age" disease with an "age-old" solution. Cancer Letters.267 (1):133-164.

Aulia OA, B Dwiloka dan M. Arifin. 2005. Perbaikan manajemen pemotongan ternak untuk menghasilkan daging sapi lokal berkualitas impor. Seminar Nasional Teknologi Peternakan dan Veteriner Universitas Diponegoro, Semarang.

Bouton PE, PV Harris and WR Shorthose. 1971. Effect of ultimate $\mathrm{pH}$ upon the water holding capacity and tenderness of mutton. Journal of Food Science.36:435-439.

Bouton PE and PV Harris. 1972. The effect of cooking temperature and time on some mechanical properties of meat. Journal of Food Science. 97:140-144.

Buckle KA, RA Edwards GH Fleet and FM Wooton. 1985. Ilmu Pangan. Penerjemah Purnomo, H. Dan Adiono. Cetakan ke-1. Universitas Indonesia Press. Jakarta.

Chattopadhyay I, K Biswas, U Bandyopadhyay and RK Banerjee. 2004. Turmeric and curcumin: Biological actions and medicinal applications. Curr. Sci.87(1):44-53.

Corzo-Martíneaz M, N Corzo and M Villamiel. 2007. Biological properties of onions and garlic. Trends Food Sci. Tech.18:609-625.

Gorinstein S, J Drzewiecki, H Leontowicz, M Leontowicz, K Najman, Z Jastrzebski, Z Zachwieja, H Barton, B Shtabsky, E Katrich and S Trakhtenberg. 2005. Comparison of the bioactive compounds and antioxidant potentials of fresh and cooked Polish, Ukrainian, and Israeli garlic. J. Agric. Food Chem.53:2726-2732.

Grashorn MA. 2010. Use of phytobiotics in broiler nutrition an alternative to infeed antibiotics? J. Anim. Feed Sci. 9:338-347.

Harris JC, S Cottrell, S Plummer and D Lloyd. 2001. Antimicrobial properties of Allium sativum(garlic). Appl. Microbiol. Biotech.57:282-286.

Isleten M, and Y Karagul-Yuceer. 2006. Effects of dried dairy ingredients on physical and sensory properties of non fat yogurt. J. Dairy Sci. 89:28652872.

Kim YJ, SK Jin and HS Yang. 2009. Effect of the dietary garlic bulb and husk on the physicochemical properties of chicken meat. Poult. Sci.88: 398 405.
Lawrie DJ. 1995. Ilmu Daging. Edisi ke-5. Diterjemahkan oleh Aminuddin Parakkasi dan Yudha Amwilla. Universitas Indonesia Press. Jakarta.

Lyon BG, DP Smith, CE Lyon and EM Savage. 2004. Effects of diet and feed withdrawal on the sensory descriptive and instrumental profiles of broiler breast fillets. Poult. Sci.83:275-281.

Mullen AM, PC Stapleton, D Corcoran, RM Hamill and A White. 2006. Understanding meat quality through the application of genomic and proteomic approaches. Meat Sci.74:3-16.

Onibi GE, OE Adebisi, AN Fajemisin and AV Adetunji. 2009. The response of broiler chickens in terms of performance and meat quality to garlic (Allium sativum) supplementation. Afr. J. Agric. Res.4:511517.

Pan MH, TM Huang and JK Lin. 1999. Biotransformation of curcumin trhough reduction and glucuronidation in mice. Drug Metab. Disp.27(4):486-494.

Panda, ASR Rao and M Raju. 2006. Natural growth promoters have potential in poultry feeding systems. Feed tech.10(8):23-35.

Panda, ASR Rao and M Raju. 2009. Phytobiotics, a natural growth promoter. Poultry International. pp:10-11.

Pearson AM and RB Young. 1989. Meat and Biochemistry. Academy Press Inc., California.

Purwanti S, Zuprizal, T Yuwanta and Supadmo. 2014a. Duodenum histomorphology and performance as influenced by dietary supplementation of Turmeric (Curcuma longa), Garlic (Allium sativum) and its combinations as a feed additive in boilers. International Journal of Poultry Science. 13(1): 3641.

Purwanti S, Zuprizal, T Yuwanta and Supadmo. 2014b. In vitro Study of Antibacterial Activity of Combination of Water Extract of Turmeric and Garlic. International Journal of Pharmacy and Life Sciences. 5(6):3580-3584.

Ravindranath V and N Chandrasekhara. 1980. In vitro studies in the intestinal absorption of curcumin in rats. Toxicology. 20(2-3):251-257.

Sami AS, C Augustini and FJ Schwarz. 2004. Effects of feeding intensity and time on feed on performance, carcass characteristics and meat quality of Simmental bulls. Meat Sci. 67:195-201.

Sarica S, A Ciftci, E Demir, K Kilinc and Y Yildirim. 2005. Use of an antibiotic growth promoter and two herbal natural feed additives with and without exogenous enzymes in wheat-based broiler diets. South Afr. J. Anim. Sci. 35: 61-72.

Soeparno. 2005. Ilmu dan Teknologi Daging. Edisi ke2. Gadjah Mada University Press. Yogyakarta.

Soeparno. 2009. Ilmu dan Teknologi Pengolahan Daging. Edisi ke-5. Gadjah Mada University Press. Yogyakarta 
Sri Purwanti, et al. /Animal Production. 20(1):61-69, 2018

Accredited by Kemenristek Dikti No 32a/E/KPT/2017. ISSN 1411-2027

Soeparno. 2011. Ilmu Nutrisi dan Gizi Daging. Cetakan pertama. Gadjah Mada University Press. Yogyakarta.

Steel RGD dan JH Torrie. 1995. Prinsip dan Prosedur Statistika. Suatu Pendekatan Biometrik. Ed ke-2. Ir. Bambang Sumantri, penerjemah. GM: Penerbit PT Gramedia Pustaka Utama. Terjemahan dari : Principles and Procedures of Statistics.
Tattelman E. 2005. Health effect of garlic. Am. Fam. Physician.72:103-106.

Van Laack RLJM, CH Liu, MO Smith and HD Loveday. 2000. Characteristics of pale, soft, exudative broiler breast meat. Poultry Science. 79:10571061. 